\title{
DEVELOPMENT OF MULTIPLEX MICROSATELLITE PANEL TO ASSESS THE PARENTAGE VERIFICATION IN AND DIFFERENTIATION DEGREE OF REINDEER POPULATIONS (Rangifer tarandus)
}

\section{V.R. KHARZINOVA', E.A. GLADYR'1, V.I. FEDOROV1, 2 , T.M. ROMANENKO3, L.D. SHIMIT ${ }^{4}$, K.A. LAYSHEV ${ }^{5}$, L.A. KALASHNIKOVA ${ }^{6}$, N.A. ZINOVIEVA ${ }^{1}$}

${ }^{1}$ L.K. Ernst All-Russian Research Institute of Animal Husbandry, Federal Agency of Scientific Organizations, pos. Dubrovitsy, Podolsk Region, Moscow Province, 142132 Russia, e-mail veronika0784@mail.ru;

${ }^{2}$ Yakutsk Research Institute of Agriculture, Federal Agency of Scientific Organizations, 23/1, ul. BestuzhevaMarlynskogo, Yakutsk, Sakha Republic,677001 Russia, e-mail vfedorov_09@mail.ru;

${ }^{3}$ Naryan-Mar Agricultural Experimental Station, Federal Agency of Scientific Organizations, 1a, ul. Rybnikov, Naryan-Mar, Nenets AO, 166004, Russia, e-mail nmshos@atnet.ru;

${ }^{4}$ Tuva State University, 36, ul. Lenina, Kyzyl, Tyva Republic, 667000 Russia, e-mail Shimit62@list.ru;

${ }_{5}^{5}$ North-West Center of Interdisciplinary Researches of Food Maintenance Problems, Federal Agency of Scientific Organizations, 7, sh. Podbel'skogo, St. Petersburg, 196608 Russia, e-mail layshev@mail.ru;

${ }^{6}$ All-Russian Research Institute of Animal Breeding, pos. Lesnye Polyany, Pushkin Region, Moscow Province, 141212 Russia, e-mail: lakalashnikova@mail.ru

Acknowledgements:

The equipment of Bioresources and Bioengineering Center of L.K. Ernst All-Russian Research Institute of Animal Husbandry was used.

Supported by the Russian Science Foundation, project № 14-36-00039

Received September 18, 2015

\section{Abstract}

Reindeer (Rangifer tarandus), the only member of the genus Rangifer, is one of the most interesting object to investigate genetic diversity. One of the technique of studying the genetic structure of populations and parentage identification is to create panels of STR (short tandem repeats) markers. The aim of the current study was the development of multiplex panel of STR markers and assessment of its application to assign the parents and to study biodiversity of Russian reindeer populations. As a biological material for research we used tissue samples (part of ear's lobes) of reindeer of Even (EVN, $n=44)$, Evenk (EVK, $n=44)$, Nenets $(n=45)$ breeds and Tyva population (TUV, $n=35$ ). DNA extraction was performed using Nexttec columns (Germany) according to the manufacturer's instructions. Polymorphism of nine STR markers (NVHRT76, RT9, NVHRT24, RT30, RT1, RT6, RT27, NVHRT21 and RT7) was determined by own procedures using ABI 3130xl DNA analyzer («Applied Biosystems», USA). Statistical analysis was performed in MS Excel 2007 with the plugin GenAIEx v. 6.5, software MSA 4.05, PHYLIP, v. 3.5c, Treev32 and Structure, v. 2.3.4. The studied populations of reindeer were characterized by relatively high levels of genetic diversity. The average number of alleles per locus was $6.11 \pm 0.56$ in TUV, $6.67 \pm 0.50$ in NEN, $8.00 \pm 0.76$ in EVN and $8.89 \pm 0.65$ in EVK. The smallest effective number of alleles per locus was detected in TUV (3.37 \pm 0.47$)$, the maximal value was in EVK (4.89 \pm 0.46 alleles per locus), and EVN and NEN occupied an intermediate position $(4.42 \pm 0.53$ and $3.90 \pm 0.38$, respectively). The number of alleles in single loci ranged from four in NVHRT21 and NVHRT24 for TUV to twelve in RT7 for EVK and RT1 for EVN. The probability of matching genotypes (PI) for the nine loci ranged from $1.84 \times 10^{-9}$ in NEN to $5.9 \times 10^{-11}$ in EVK, showing the high power of the proposed marker panel for parentage identification. The calculation of the mean values of similarity coefficient $Q$ in the $i_{\text {th }}$ cluster with the most probable number of clusters such as $k=3$ and $k=4\left(Q_{i / k}\right)$ revealed high heterogeneity of genetic structure of studied populations. The highest degree of genetic differentiation was shown for TUV $\left(\mathrm{Q}_{2 / 3}=0.899 \pm 0.034, \mathrm{Q}_{3 / 4}=0.883 \pm 0.035\right)$ and for $\mathrm{NEN}\left(\mathrm{Q}_{3 / 3}=0.885 \pm 0.031, \mathrm{Q}_{4 / 4}=0.813 \pm 0.038\right)$. The EVN and EVK population were close to each other, and a clear clustering between them was not observed. An estimation of $\mathrm{R}_{\mathrm{st}}$ (AMOVA) showed that $11.4 \%$ of the total molecular variability was caused by differences between populations, and $88.6 \%$ was due to individual differences between animals $(\mathrm{p}<0.01)$. Evaluation of degree of genetic differentiation of studied populations, using as criteria the values of Nei' genetic distances and pairwise comparisons of $\mathrm{F}_{\mathrm{st}}$ showed similar trends. TUV population was the most distinct comparing to other populations $\left(\mathrm{D}_{\mathrm{Nei}}=0,283-0,502, \mathrm{~F}_{\mathrm{st}}=0,299-0,452\right)$, while it was the most differ from NEN and the closest to EVN. The minimal genetic differences were observed between EVN and EVK $\left(D_{\mathrm{Nei}}=0,068, \mathrm{~F}_{\mathrm{st}}=0,032\right)$. The results show high functional power of the developed STR panel to identify the parentage and to study biodiversity in Russian reindeer populations. 
Molecular genetic studies of species and breeds of farm animals are an important in the system of conservation and use of biological resources [1]. While the genetic structure is adequately characterized in the main types of domestic animals, many species of local importance remain poorly studied.

Reindeer (Rangifer tarandus)is the most important element of the ecosystems and an integral part of indigenous peoples' life and culture in the North [2]. This species is the only member of the genus Rangifer, belongs to the Cervidae (deer) family of the Ruminants suborder, and one of the few species in which the wild form coexist with the domestic one. Most scientists believe that reindeer forms 12-15 subspecies, including 5-7 subspecies in Russia. Thus, according to one concept, all North European deer belong to the $R$. tarandus tarandus L. subspecies (European reindeer) [3-5]. According to other concepts, European territory is inhabited by 2 subspecies, the $R$. $t$. fennicus Lönn (Eurasian forest reindeer ) and $R . t$. tarandus L. (Eurasian tundra reindeer) [6-9].

Breed formation processes in northern reindeer husbandry have a lot in common with the breed genesis of other species of domesticated animals such as horses, sheep, yaks, camels, etc. Breed specialty is based on the folk traditional breeding system and the complete lack of commercial incentive, which later appeared in stud breeding in Europe and North America [10]. It is generally accepted to identify four native breeds of semi-domesticated reindeer created by the northern Russian nationalities which are different in their specialization, exterior constitutional features and adaptiveness to the specific climatic conditions, i.e. the Nenets, Chukchi, Evenki and Even breeds [11].

Nenets reindeer is bred in the north of European Russia and east of the Urals, in the lower reaches of the Ob' and Yenisei rivers. Currently, this breed is the most numerous and prosperous one. Chukchi reindeer inhabit the territory of Chukotka and Kamchatka peninsulas and the northeast of Yakutia. Evenk breed is bred in the taiga zone of Siberia and the Far East within the area from the Yenisey River to the shores of the Sea of Okhotsk and Sakhalin Island. Several inbreed groups are identified in the breed. The mountain-taiga regions of Yakutia, Kamchatka and Magadan regions are the Even breed habitat (in its type, it occupies an intermediate position between the Chukchi and Evenki breeds). Consolidation and the study of the genetic structure and biology of Even breed are in process. Several breed groups are identified in reindeer as well, with exterior constitutional features in each; yet these groups have not got the breed status. Thus, the large Tuvan population animals (Todzha Region, Republic of Tyva) are of interest. Some scientists consider them as an independent breed group of the Tuvan Tofalar type [12].

Currently, reindeer breeding uses conventional methods, and the most complete picture of the population structure can be obtained based on the analysis of a range of various biological parameters, including genetic ones.

The study of reindeer genetic diversity has always been of intense interest. Research began in the 1960s, when a simple and quick methods of electrophoresis in agar, starch and acrylamide gel were introduced in population genetics widely. Later, the studies of serum transferrin polymorphism were reported [13-16]. With the development of molecular genetics, application of more precise methods became possible for the direct analysis at the DNA level with a higher capacity as compared to the previously used marker systems [17, 18].

Informativeness of DNA analysis is largely determined by the type and number of DNA markers used. In this context, creating multiplex panels of DNA marker analysis to study genetic characteristics of animal species and breeds is 
relevant. Among the variety of marker systems, microsatellites also known as short tandem repeats (STR) are the most widespread ones. Due to the high degree of polymorphism, Mendelian type of inheritance and uniform genome-wide distribution, STR panels are used in all major farm animal species [19]. They are used to control the reliability of parentage, determine the degree of inbreeding, to assess breed purity, characterize the biodiversity and the degree of genetic differentiation of breeds and inbreed genetic structures [20-23]. Currently, there are many publications that demonstrate the applied relevance of STR in the characterization of the reindeer gene pool STR [24-32], but the Russian reindeer breeds and population have not been studied yet.

The purpose of this study was to develop a multiplex panel of STR markers to assess the reliability of parentage assignment and the degree of differentiation of Russian native reindeer populations.

Technique. Reindeer (Rangifer tarandus) of Even (EVN, «Yuchyugeyskoe» enterprise, Sakha Republic, $n=44)$, Evenk (EVK, «Taba» enterprise, Sakha Republic, $n=44$ ), Nenets (NEN, «Indigo» enterprise, Nenets Autonomous Okrug, $n=45$ ) breeds and Tyva population (TUV, Todzha, Republic of Tyva, $n=35$ ) were studied. Ear tissue samples were used as biological material. DNA extraction was performed using Nexttec columns (Nexttec ${ }^{\mathrm{TM}}$ Biotechnologie $\mathrm{GmbH}$, Germany) according to manufacturer recommendations.

Based on the analysis of specialized publications, 9 STR markers were selected, including 3 loci developed for reindeer (NVHRT21, NVHRT24, NVHRT76) [18], and 6 loci developed for caribous (RT1, RT6, RT7, RT9, RT27, RT30) [33], formed into a single multiplex panel. PCR analysis was performed in a final volume of 15 microliters. For assay, $1 \mu \mathrm{l}$ (50-100 ng) of investigated genomic DNA was added to each tube with $14 \mu \mathrm{l}$ of reaction mixture consisting of $1.5 \mu \mathrm{l}$ of $10 \times$ PCR buffer, $1.5 \mu \mathrm{l}$ of $2 \mathrm{mM}$ dNTPs solution, $0.15 \mu \mathrm{l}$ of $100 \mathrm{mM} \mathrm{MgCl}_{2}, 2.54 \mu \mathrm{l}$ of $10 \mathrm{mM}$ mixture of primers, $0.2 \mu \mathrm{l}$ (1 unit) of Taq polymerase (Dialat Ltd., Russia), and $8.01 \mu \mathrm{l}$ of bidistilled water. In the PCR buffer there was $16.6 \mathrm{mM}\left(\mathrm{NH}_{4}\right)_{2} \mathrm{SO}_{4}, 67.7 \mathrm{mM}$ Tris-HC1 $(\mathrm{pH}=8.8)$, supplemented with Tween 20 ( 0.1 of the mixture volume). After initial denaturation $\left(94{ }^{\circ} \mathrm{C}, 5 \mathrm{~min}\right), 30$ amplification cycles were performed $\left(95{ }^{\circ} \mathrm{C}, 1 \mathrm{~min}\right.$; $55{ }^{\circ} \mathrm{C}$, $\left.30 \mathrm{sec} ; 72{ }^{\circ} \mathrm{C}, 1 \mathrm{~min}\right)$. Annealing treatment regimen was calculated based on the melting temperature of the primers. Fragments were analyzed using a ABI3130xl (Applied Biosystems, USA) genetic analyzer. Allele sizes were determined using the Gene Mapper v. 4 software (Applied Biosystems, USA). A Microsoft Excel genotype matrix was used to process the results of the analysis.

To characterize the allele pool, the average number of alleles $(\mathrm{Na})$ and the number of effective alleles $\left(\mathrm{N}_{\mathrm{e}}\right)$ per locus, the extent of the observed $\left(\mathrm{H}_{\mathrm{o}}\right)$ and expected heterozygosity $(\mathrm{He})$, information Shannon index (I) and the index of fixation $\left(\mathrm{F}_{\mathrm{is}}\right)$ were determined [34]. Informativeness of the developed STR panel for the control of parentage reliability was evaluated for the genotype identity probability (PI) [35] and parents' probability exception (P1, P2, P3) [36, 37].

Genetic population structure was evaluated using cluster analysis according J.K. Pritchard et al. [38] without introduction of preliminary information about individual population affiliation. Average values of similarity coefficient $Q$ in the $i$-th cluster for the total number of clusters $\mathrm{k}\left(\mathrm{Q}_{\mathrm{i} / \mathrm{k}}\right)$ were calculated for each group. The proportion of population variability to total variability was estimated based on the $R_{s t}$ value (AMOVA) [39]. The degree of population genetic differentiation was estimated based on $F_{\text {st }}$ values [40] and genetic distances for M. Nei [41].

Statistical data processing was performed using the MS Excel 2007 pack- 
age with the GenAIEx v. 6.5.1 plugin [42], Phylip (v. 3.5c) [43] and Structure 2.3.4 [38] software.

Results. Selection of microsatellite loci for inclusion in the STR panel was performed based on their polymorphic nature and on the possibility of their amplification in a single reaction (close primer melting temperatures) and analyzing with DNA analyzer using specific fluorescent labels (spectra for each stain do not overlap). As a result, we proposed the STR panel that enables simultaneous analysis of 9 loci (Fig. 1).

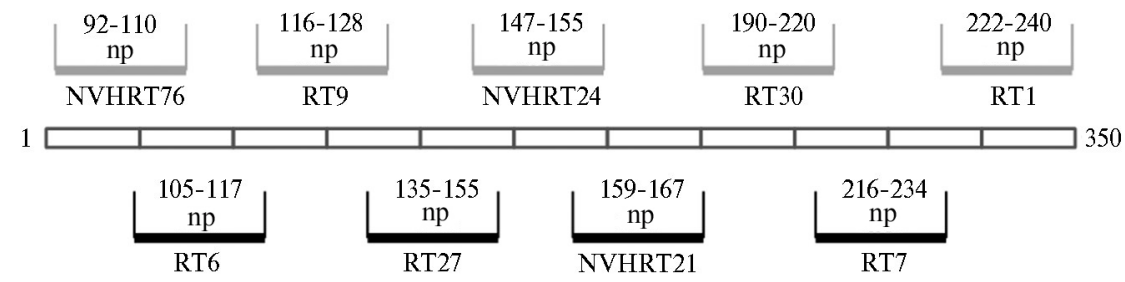

Fig. 1. Diagram of multiplex system developed for the analysis of 9 STRs in reindeer Rangifer tarandus. FAM and HEX fluorescent labeled fragments are shown in gray and black, respectively.

The studied reindeer populations were characterized by relatively high levels of genetic diversity. The average allele number per locus was $6.11 \pm 0.56$ in TUV, 6.67 \pm 0.50 in NEN, 8.00 \pm 0.76 in EVN, and 8.89 \pm 0.65 in EVK. The same regularity was observed in the number of effective alleles. Particularly, the lowest number of effective alleles was observed in TUV group (3.37 \pm 0.47 alleles per locus), the maximum value was in EVK (4.89 \pm 0.46 alleles per locus), EVN and NEN groups occupied an intermediate position $(4.42 \pm 0.53$ and $3.90 \pm 0.38$, respectively). The number of alleles in single loci ranged from 4 (in NVHRT21 and NVHRT24 loci for TUV) to 12 (in RT7 for EVK and RT1 for EVN). Calculation of $\mathrm{H}_{\mathrm{o}}$ and $\mathrm{H}_{\mathrm{e}}$ demonstrated a substantial deficit of heterozygotes for all groups (from 10 to $16 \%$ ). This was also confirmed by high positive $F_{\text {is }}$ values. However, the values of Shannon's information index indicated a sufficiently high genetic diversity in three of the four groups studied ( $\mathrm{I} \geq 1.5$ ), except TUV (Table 1).

1. Genetic diversity of studied reindeer Rangifer tarandus breeds for microsatellite loci

\begin{tabular}{l|c|c|c|c|c}
\hline \multirow{2}{*}{$\begin{array}{l}\text { Breed/geographical } \\
\text { group }\end{array}$} & \multicolumn{2}{|c|}{ Degree of heterozygosity } & \multirow{2}{*}{$\mathrm{H}_{\mathrm{o}}-\mathrm{H}_{\mathrm{e}}$} & $\mathrm{I}$ & \multirow{2}{*}{$\mathrm{F}_{\text {is }}$} \\
\cline { 2 - 5 } & $\mathrm{H}_{\mathrm{O}}$ & $\mathrm{H}_{\mathrm{e}}$ & & & $0.15 \pm 0.05$ \\
EVN & $0.63 \pm 0.04$ & $0.74 \pm 0.03$ & -0.11 & $1.608 \pm 0.108$ & $0.13 \pm 0.04$ \\
EVK & $0.68 \pm 0.04$ & $0.78 \pm 0.02$ & -0.10 & $1.752 \pm 0.089$ & $0.21 \pm 0.08$ \\
NEN & $0.56 \pm 0.05$ & $0.72 \pm 0.03$ & -0.16 & $1.517 \pm 0.089$ & $0.18 \pm 0.07$ \\
TUV & $0.55 \pm 0.06$ & $0.67 \pm 0.04$ & -0.12 & $1.363 \pm 0.111$ & $0.17 \pm 0.03$ \\
Average & $0.61 \pm 0.03$ & $0.73 \pm 0.02$ & -0.12 & $1.560 \pm 0.053$ & \\
\hline
\end{tabular}

Note. EVN, EVK, NEN, TUV - Even, Evenk, Nenets breeds and Tyva population (for description, see section Methods); $\mathrm{H}_{\mathrm{o}}$ - observed heterozigosity $\mathrm{H}_{\mathrm{e}}-$ expected heterozigosity, $\mathrm{I}-$ Shannon index, $\mathrm{F}_{\text {is }}-$ index of fixation.

The probability of matching genotypes (PI) for the developed STR panel ranged from $1.84 \times 10^{-9}$ in NEN to $5.9 \times 10^{-11}$ in EVK, i.e. it was practically impossible. The values of exclusion probability (P1, P2, P3), calculated according to the results of the STR panel analysis, were minimal in TUV and maximum in EVK and ranged from 99.61 to $99.97 \%$ for P1 (one parent exclusion with the genotypes of both parents known), from 95.36 to $99.30 \%$ for P2 (parent exclusion with the genotype of one parent known) and from 99.94 to $>99.99 \%$ for P3 (exclusion of both parents). These data confirm high informativeness of DNA 
analysis for parentage assignment in reindeer and the functional capacity of the STR panel developed.

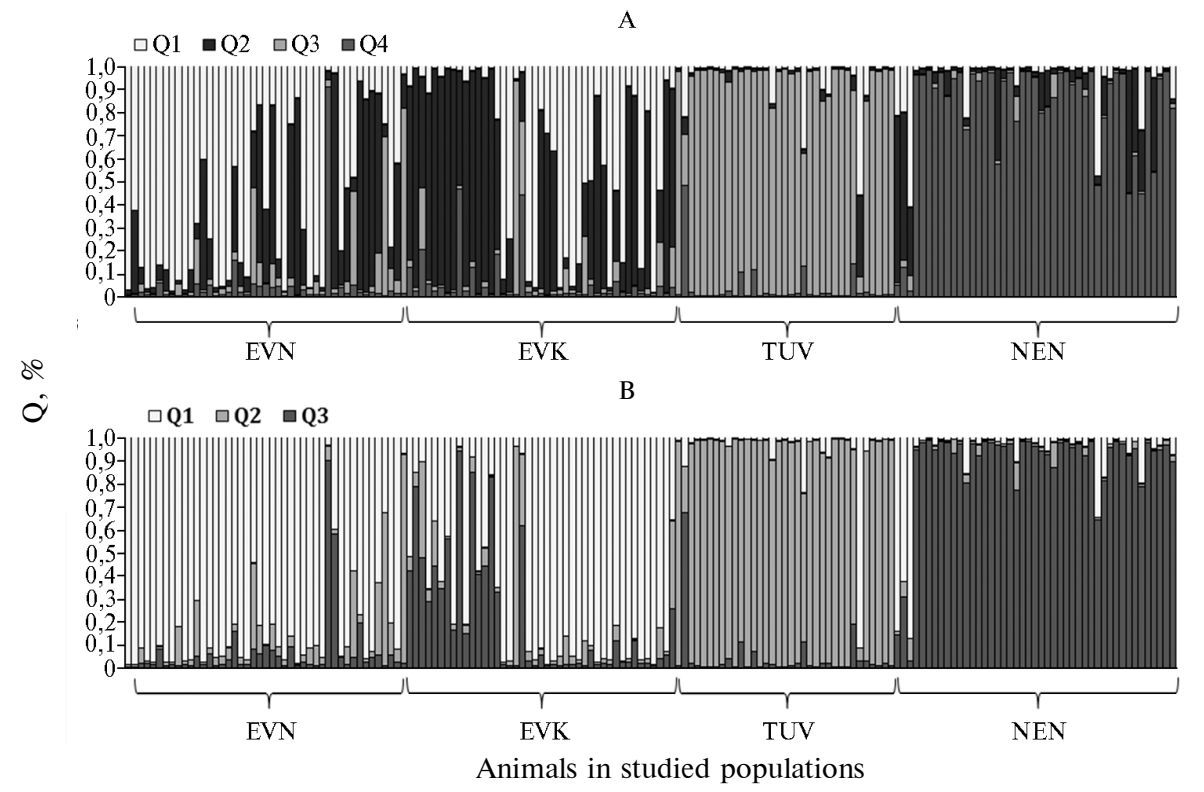

Fig. 2. Results of genetic structure analysis for the reindeer Rangifer tarandus populations studied for the number of clusters of $k=3$ (А) и $k=4$ (В): EVN, EVK, NEN, TUV - Even, Evenk, Nenets breeds and Tyva population (for description, see section Methods); Q1-Q4 - values of similarity coefficient $\mathrm{Q}$ in the relevant cluster. Q values are calculated according to J.K. Pritchard et al. [38].

The results of cluster analysis with the most probable number of clusters such as $\mathrm{k}=3$ (Fig. 2, A) and $\mathrm{k}=4$ (Fig. 2, B) revealed high heterogeneity of genetic structure of studied populations. The highest degree of genetic differentiation was shown for $\operatorname{TUV}\left(\mathrm{Q}_{2 / 3}=0.899 \pm 0.034, \mathrm{Q}_{3 / 4}=0.883 \pm 0.035\right)$ and for NEN $\left(Q_{3 / 3}=0.885 \pm 0.031, Q_{4 / 4}=0.813 \pm 0.038\right)$; it should be noted that one specimen in TUV population $\left(\mathrm{Q}_{1 / 3}=0,912, \mathrm{Q}_{1 / 4}+\mathrm{Q}_{2 / 4}=0,914\right)$, and three specimens in NEN population $\left(\mathrm{Q}_{1 / 3}=0,624-0,870, \mathrm{Q}_{1 / 4}+\mathrm{Q}_{2 / 4}=0,838-0,935\right)$ stood apart having genetically different origin close to EVN and EVK groups (clusters $\mathrm{Q}_{1 / 3}$ and $\mathrm{Q}_{1 / 4}+\mathrm{Q}_{2 / 4}$ ). Genetically, one specimen in TUV population was mostly close to $\mathrm{NEN}\left(\mathrm{Q}_{3 / 3}=0.676\right.$ and $\left.\mathrm{Q}_{4 / 4}=0.485\right)$.

The EVN and EVK populations were less differentiated, and a clear clustering between them was not observed. The average values of similarity coefficient were $\mathrm{Q}_{1 / 3}=0.768 \pm 0.030$ and $\mathrm{Q}_{1 / 4}+\mathrm{Q}_{2 / 4}=0.874 \pm 0.021$. Genetically, two EVN specimens were assigned to $\operatorname{TUV}\left(\mathrm{Q}_{2 / 3}=0.666\right.$ and $\left.\mathrm{Q}_{3 / 4}=0.690\right)$ and $\operatorname{NEN}\left(\mathrm{Q}_{3 / 3}=0.903\right.$ and $\left.\mathrm{Q}_{4 / 4}=0.912\right)$, and two EVK specimens were assigned to $\operatorname{TUV}\left(\mathrm{Q}_{2 / 3}=0.905-0.950\right.$ and $\left.\mathrm{Q}_{3 / 4}=0.808-0.927\right)$.

Cluster analysis results confirmed the data of genetic distance calculation according to M. Nei (Fig. 3). The close genetic relationship between EVN and EVK, on the one hand, and the heterogeneity of their genetic structure, on the other hand, was manifested in the formation of common clusters in the family tree. TUV reindeer (except for 3 specimens) were combined into a single cluster which also included 4 specimens of three other populations. A large group of NEN specimens (32 out 45 animals studied) stood out forming a separate cluster that also includes $4 \mathrm{EVN}$ and $1 \mathrm{EVK}$ specimens. EVN and EVK animals formed several mixed clusters with TUV (3 specimens) and NEN (3 specimens) deer localized in some of them. 


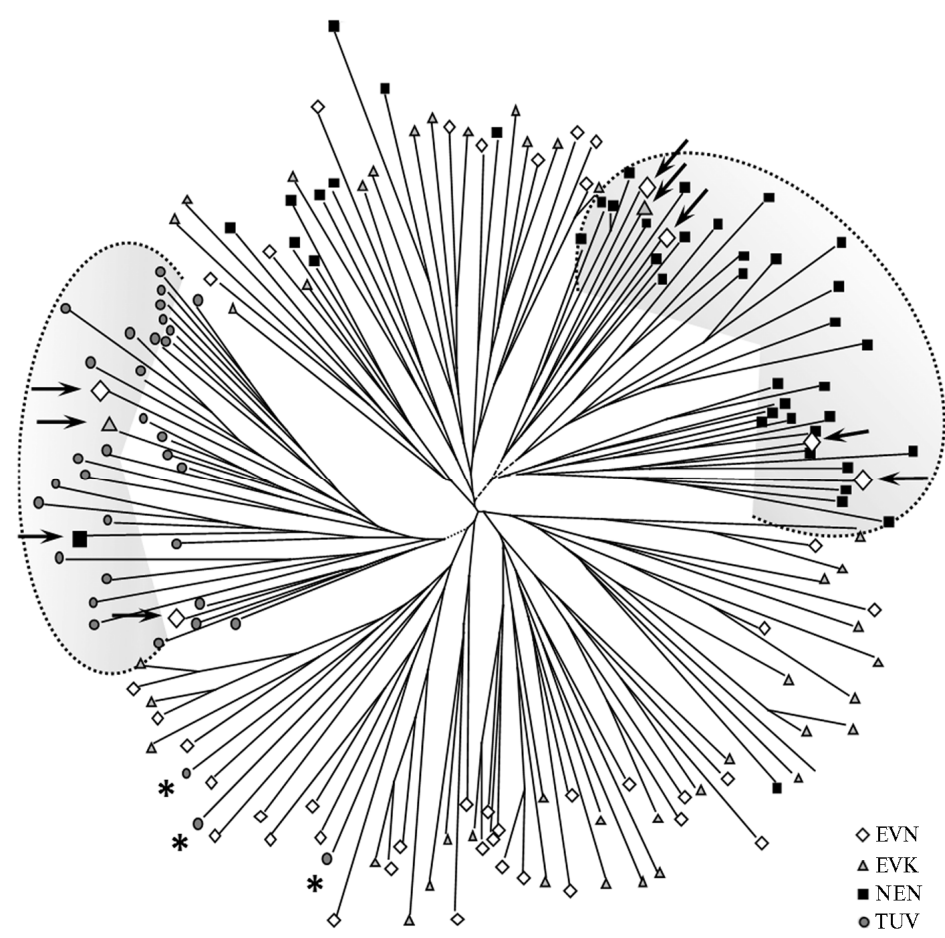

Fig. 3. Dendrogram of genetic distances for the specimens of studied Rangifer tarandus reindeer populations constructed according to $\mathrm{M}$. Nei [41] by UPGMA: EVN, EVK, NEN, TUV - Even, Evenk, Nenets breeds and Tyva population (for description, see section Methods). Asterisks denote TUV specimens in a «foreign» cluster, arrows denote the specimens of other populations in NEN and TUV clusters.

\section{Genetic differentiation of the studied Rangifer tarandus reindeer populations}

\begin{tabular}{l|c|c|c|c}
\hline \multicolumn{1}{c|}{ Breed/geographical group } & EVN & EVK & NEN & TUV \\
\hline EVN & & 0.068 & 0.259 & 0.283 \\
EVK & 0.032 & & 0.273 & 0.356 \\
NEN & 0.251 & 0.251 & & 0.502 \\
TUV & 0.299 & 0.347 & 0.452 &
\end{tabular}

N o t e. EVN, EVK, NEN, TUV - Even, Evenk, Nenets breeds and Tyva population (for description, see section Methods). Above the diagonal the genetic distances according to M. Nei [41] are shown; below the diagonal there are the pairwise values of $F_{\text {st }}$.

Estimation of $\mathrm{R}_{\mathrm{st}}$ (AMOVA) showed that $11.4 \%$ of the total molecular variability was caused by differences between populations, and $88.6 \%$ was due to individual differences between animals $(\mathrm{p}<0.01)$. Evaluation of the degree of population genetic differentiation using the values of genetic distances according to $\mathrm{M}$. Nei and pairwise values of $\mathrm{F}_{\mathrm{st}}$ as criteria, demonstrated similar tendencies. TUV population was the most distinct one compared to other populations, while it was mostly differentiated from NEN and the closest to EVN. TUV population was almost equidistant from EVN and EVK. The minimal genetic differences were observed between EVN and EVK (Table 2).

To evaluate reindeer biodiversity, STR panels which differ in both the number and the range of markers, are used. K. Røed and L. Midthjell [18] studied two semi-domesticated $R$. tarandus Norway reindeer populations using 23 STRs, 6 of which appeared to be monomorphic and 17 were characterized by the average number of alleles per locus of 3 to 10. A. McDevitt et al. [25] described genetic structure of $R$. $t$. groenlandicus and $R$. $t$. caribou populations in North America using 11 STR. G. Wilson et al. [33] demonstrated that of the 13 STRs developed for caribou, 12 were polymorphic in the Canadian reindeer population with the number of alleles per locus of 4 to 8 . S. Côté et al. [44] used 
14 STRs in a comparative study of reindeer diversity in two Svaldbar populations (the number of alleles per locus of 1 to 5). R. Courtois and L. Bernatchez [45] applied 8 STRs, including 7 loci developed for caribou [33], and one cattle STR to evaluate the biodiversity of seven caribou populations in North America (number of alleles per locus of 3 to 20).

We proposed a multilocus panel which makes it possible to simultaneously analyze nine STRs. All of them were polymorphic in the studied populations of Russian reindeer, i.e. the number of alleles per locus ranged from 4 in NVHRT21 and NVHRT24 for TUV to 12 in RT1 for EVN and in RT7 for NEN. Russian $R$. tarandus populations were characterized by higher genetic diversity in the number of alleles per locus compared to other populations studied (Table 3).

3. Comparative analysis of nine STRs' biodiversity in Rangifer tarandus reindeer populations

\begin{tabular}{|c|c|c|c|c|c|c|c|}
\hline \multirow{2}{*}{ STR } & \multicolumn{7}{|c|}{ Allele numbers in STR locus in populations } \\
\hline & EVN & EVK & NEN & TUV & $\mathrm{A}$ & B & $\mathrm{CC}$ \\
\hline Deer number, $n$ & 44 & 44 & 45 & 35 & 23 & 182 & 561 \\
\hline NVHRT21 & 5 & 8 & 6 & 4 & 5 & - & - \\
\hline NVHRT24 & 6 & 6 & 5 & 4 & 5 & - & - \\
\hline NVHRT76 & 6 & 7 & 6 & 6 & 6 & - & - \\
\hline RT1 & 12 & 11 & 9 & 6 & - & 2 & 2 \\
\hline RT6 & 7 & 8 & 9 & 5 & - & 2 & 2 \\
\hline RT7 & 11 & 12 & 7 & 9 & - & 4 & 3 \\
\hline RT9 & 8 & 8 & 7 & 7 & - & 1 & 1 \\
\hline RT27 & 8 & 10 & 6 & 6 & - & - & - \\
\hline RT30 & 7 & 10 & 5 & 8 & - & 2 & 2 \\
\hline
\end{tabular}

N o t e. EVN, EVK, NEN, TUV - Even, Evenk, Nenets breeds and Tyva population (for description, see section Methods); A - two Central Norway domesticated reindeer herds [18], B - semi-domesticated reindeer, Sassendalen, Svalbard [44], B - semi-domesticated reindeer, Kolesdalen/Reyndalen, Svalbard [44]. Dashes mean that populations have not been studied.

In some studies [44, 45], a lower genetic diversity is estimated in reindeer isolated populations in Europe and North America, which was consistent with our results for the Russian populations of $R$. tarandus. Minimum genetic diversity estimated by the average number of alleles per locus, by the heterozygosity extent observed and by Shannon information index, was characteristic of TUV population that was geographically isolated from other populations studied, maximum diversity was found in EVN and EVK with overlapping habitats. Blood mixing with the Even breed of Oymyakon district of the Republic of Sakha (Yakutia) may be one of the reasons for the high heterogeneity of EVK population and its similarity to EVN. Therefore, to further evaluate the gene pool of Russian reindeer breeds, it is necessary to expand the number and geographical diversity of populations studied, as well as to use genetically pure populations (continuous breeding without blood mixing and geographic isolation).

Thus, heterogeneity of the genetic structure of all reindeer populations studied has been shown, with genetic purity and separateness being the greatest in Tuvan population, and the lowest in Even and Evenki populations. These results demonstrate the feasibility of using the microsatellite multiplex panel developed as one of the methods to identify genetic differences between populations. This will help to clarify parentage history, the boundaries and propagation paths of individual populations and will be a basis for the further study of the diversity of one of the most unique representatives of the Cervidae family. Furthermore, we suggest a multilocus panel which serves as a tool in assessing individual parentage validity. Its application will radically improve selection and breeding and make it possible to develop a system of genomic assessment in northern reindeer herding. 


\section{R E F E R E N C E S}

1. Stolp ovs ki i Yu.A. Vavilovskii zhurnal genetiki i selektsii, 2013, 17(4/2): 900-902.

2. Davydov A.B. Morfologicheskaya $i$ geneticheskaya differentsiatsiya populyatsii severnogo olenya Evrazii. Avtoreferat kandidatskoi dissertatsii [Morphological and genetic differentiation in the Eurasia reindeer population. PhD Thesis]. Moscow, 1997.

3. Fle rov K.K. Fauna SSSR. Mlekopitayushchie. Kabargi i oleni [Fauna o the USSR. Mammals. Musk-deer and reindeer]. Moscow, 1952.

4. Ge pt ne r V.G., N a s i m ovi ch A.A., B a n nikov A.G. Mlekopitayushchie Sovetskogo Soyuza [Mammals of the USSR]. Moscow, 1961.

5. D a nilk i n A.A. Olen'i (Cervidae) [Deers (Cervidae)]. Moscow, 1999.

6. B a nfi eld A.W.F. A revision of the reindeer and caribou genus, Rangifer. Bulletin № 177. National Museum of Canada, Ottawa, 1961.

7. Kupriyanov A.G. Materialy 2-go Mezhdunarodnogo simpoziuma «Dinamika populyatsii okhotnich'ikh zhivotnykh Severnoi Evropy» [Proc. II Int. Symp. «Population dynamics of game animals in North Europe»]. Petrozavodsk, 1998: 25-26.

8. Danilov P.I. Okhotnich'i zhivotnye Karelii: ekologiya, resursy, upravlenie, okhrana [Game animals in Karelia: ecology, resources, control, protection]. Moscow, 2005.

9. Da nilov P.I., P a n c he n k o D.V. Sovremennye problemy prirodopol'zovaniya, okhotovedeniya i zverovodstva, 2012, 1: 88-92.

10. Y u zh a k ov A.A., M u h a c h e v A.D. Agrarnaya nauka, 2002, 10: 7-8.

11. Ernst L.K., D m i tri e v N.G., P a r o n y n I.A. Geneticheskie resursy sel'skokhozyaistvennykh zhivotnykh $v$ Rossii $i$ sopredel'nykh stranakh [Genetic resources of farm animals in Russia and neighbouring countries]. St. Petersburg, 1994.

12. P o m is hi n S.B. Problemy porody $i$ ee sovershenstvovanie $v$ olenevodstve [Breed and its improvement under reindeer herding]. Yakutsk, 1981.

13. Storset A., Olais e n B., Wika M., Bjarghov R. Genetic markers in the Spitzbergen reindeer. Hereditas, 1978, 88: 113-115.

14. Baccus R., Ryman N., S mith M.H., Reuterwall C., Came ron D. Genetic variability and differentiation of large grazing mammals. J. Mammalogy, 1983, 64: 109-120 (doi: 10.2307/1380756).

15. R o e d K.H. Genetic differences at the transferrin locus in Norwegian semidomestic and wild reindeer (Rangifer tarandus L.). Hereditas, 1985, 102: 199-206.

16. Cronin M.A., Renecker L., Pierson B.J., Pat to n J.C. Genetic variation in domestic reindeer and wild caribou in Alaska. Anim. Genet., 1995, 26: 427-434.

17. Romanenko T.M., Kalashnikova L.A., Filippova G.I., Laishev K.A. Dostizheniya nauki i tekhniki APK, 2014, 4: 68-71.

18. Røe d K.H., M idth je 11 L. Microsatellites in reindeer, Rangifer tarandus, and their use in other cervids. Mol. Ecol., 1998, 7: 1773-1776 (doi: 10.1046/j.1365-294x.1998.00514.x).

19. Zinovieva N.A., Kharzinova V.R., Logvinova T.I., Gladyr' E.A., S i z a reva E.I., C h i n a rov Yu.I. Sel'skokhozyaistvennaya biologiya [Agricultural Biology], 2011, 6: 47-53.

20. W e b e r J.L., M a y P.E. Abundant class of human DNA polymorphisms which can be typed using the polymerase chain reaction. Am. J. Hum. Genet., 1989, 44(3): 388-396.

21. Tautz D. Hypervariability of simple sequences as a general source for polymorphic DNA markers. Nuc. Acids Res., 1989, 17: 6463-6471.

22. De Wo ody J., Avise J.C. Microsatellite variation in marine, freshwater and anadromous fishes compared with other animals. J. Fish Biology, 2000, 56: 461-473 (doi: 10.1111/j.10958649.2000.tb00748.x).

23. Prim m e r C.R., Elle gre n H., S a i n o N., Mølle r A.P. Directional evolution in germline microsatellite mutations. Nat. Genet., 1996, 13: 391-393.

24. B a 11 M.C., Finnegan L., M a nsea u M., Wils o n P. Integrating multiple analytical approaches to spatially delineate and characterize genetic population structure: an application to boreal caribou (Rangifer tarandus caribou) in central Canada. Conserv. Genet., 2010, 11: 2131 2143 (doi: 10.1007/s10592-010-0099-3).

25. McDevitt A.D., Mariani S., Hebblewhite M., DeCesare N.J., Morganti ni L., S e ip D., We ckworth B.V., Musiani M. Survival in the Rockies of an endangered hybrid swarm from diverged caribou (Rangifer tarandus) lineages. Mol. Ecol., 2009, 18: 665-679 (doi: 10.1111/j.1365-294X.2008.04050.x).

26. Zittlau K.A., Coffin J., Farnell R.S., Kuzyk G.W., Strobeck C. Genetic relationships of three Yukon caribou herds determined by DNA typing. Rangifer, 2000, 12: 59-62 (doi: $10.7557 / 2.20 .5 .1625)$.

27. Kol N.V., La z e b n y i O.E. Genetika, 2006, 42(12): 1731-1734.

28. $\mathrm{C}$ ro n i n M.A. Intraspecific variation in mitochondrial DNA of North American cervids. $J$. Mammalogy, 1992, 73(1): 70-82 (doi: 10.2307/1381867).

29. C ronin M.A., M a c Neil M.D., P at to n J.C. Variation in mitochondrial DNA and mi- 
crosatellite DNA in caribou (Rangifer tarandus) in North America. J. Mammalogy, 2005, 86: 495-505 (doi: 10.1644/1545-1542(2005)86\%5B495:VIMDAM\%5D2.0.CO;2).

30. Enge 1 S.R., Li n n R.A., T a y lo r J.F., D a vis S.K. Conservation of microsatellite loci across species of artiodactyls: implications for population studies. J. Mammalogy, 1996, 77: 504518 (doi: 10.2307/1382825).

31. Z ittlau K.A. Population genetic analyses of North American caribou (Rangifer tarandus). PhD Thesis. University of Alberta, Canada, 2004.

32. Tyler S.K., McFarlane K.A., Pamela Groves P., Mooers A.Ø., Shapiro B. Modern and ancient DNA reveal recent partial replacement of caribou in the southwest Yukon. Mol. Ecol., 2010, 19: 1312-1323 (doi: 10.1111/j.1365-294X.2010.04565.x).

33. Wils o n G.A., Strobeck C., Wu L., C offi n J.W. Characterization of microsatellite loci in caribou Rangifer tarandus, and their use in other artiodactyls. Mol. Ecol., 1997, 65: 697699 (doi: 10.1046/j.1365-294X.1997.00237.x).

34. Ha rt 1 D.L., C la r k A.G. Principles of population genetics. Massachusetts, 1997.

35. Waits L.P., Luikart G., Taberlet P. Estimating the probability of identity among genotypes in natural populations: cautions and guidelines. Mol. Ecol., 2001, 10: 249-256 (doi: 10.1046/j.1365-294X.2001.01185.x).

36. J a mies on A. The effectiveness of using co-dominant polymorphic allelic series for (1) checking pedigrees and (2) distinguishing full-sib pair members. Anim. Genet., 1994, 25(1): 37 44 (doi: 10.1111/j.1365-2052.1994.tb00401.x).

37. J a mi e s o n A., T a y lor S.C.S. Comparisons of three probability formulae for parentage exclusion. Anim. Genet., 1997, 28: 397-400 (doi: 10.1111/j.1365-2052.1997.00186.x).

38. Pritchard J.K., Stephens M., D o n nelly P. Inference of population structure using multilocus genotype data. Genetics, 2000, 155: 945-959.

39. S l at k i n M.A. A measure of population subdivision based on microsatellite allele frequencies. Genetics, 1995, 139: 457-462.

40. We i r B.S., C o c k e r h a m C.C. Estimating F-statistics for the analysis of population structure. Evolution, 1984, 38: 1358-1370.

41. N e i M. F-statistics and analysis of gene diversity in subdivided populations. Ann. Hum. Genet., 1977, 41: 225-233.

42. Peakall R., S mouse P.E. GenAlEx 6.5: genetic analysis in Excel. Population genetic software for teaching and research-an update. Bioinformatics, 2012, 28: 2537-2539 (doi: 10.1093/bioinformatics/bts460).

43. F e ls e n st e i n J. Phylip (Phylogeny Inference Package) version 3.5c. Seattle, 1993.

44. Côté S.D., Dallas J.F., Marshall F., I rvine R.J., Langvatn R., Albon S.D. Microsatellite DNA evidence for genetic drift and philopatry in Svalbard reindeer. Mol. Ecol., 2002, 11: 1923-1930 (doi: 10.1046/j.1365-294X.2002.01582.x).

45. Courtois R., Bernatchez L., Ouellet J.-P., B reton L. Significance of caribou (Rangifer tarandus) ecotypes from a molecular genetics viewpoint. Conservation Genetics, 2003, 4: 393-404. 